\title{
Identifikasi Pengembangan Daya Tarik Wisata Pada Dusun Kabo Jaya, Desa Swarga Bara, Kecamatan Sangatta Utara, Kabupaten Kutai Timur
}

\author{
Muhammad Fauzan Noor ${ }^{\mathrm{a}, 1, *}$, Justina Ade ${ }^{\mathrm{b}, 2}$, Fareis Althalets ${ }^{\mathrm{c}, 3}$ (11pt) \\ ${ }^{a}$ Politeknik Negeri Samarinda,Samarinda,75131, Indonesia (9 font) \\ ${ }^{b}$ Universitas Mulawarman, Gunung Kelua, Samarinda, 75117, Indonesia (9 font) \\ ${ }^{c}$ Universitas Mulawarman, Gunung Kelua, Samarinda, 75117, Indonesia (9 font) \\ Im.fauzan_noor@polnes.ac.id*; ${ }^{2} y u s t i n a . a d e @ g m a i l . c o m ;{ }^{3}$ althaletsfareis@gmail.com (9 font) \\ *Muhammad Fauzan Noor
}

Article history:

Received

Revised

Accepted
Munculnya konsep ekowisata merupakan salah satu bentuk wisata alternativ yang mengadopsi prinsip-prinsip pariwisata berkelanjutan, aktifitas wisata ini lebih fokus pada kepedulian terhadap upaya konservasi alam dan budaya. Desa Kabo Jaya yang berada berdampingan dengan Taman Nasional Kutai (TNK) mempunyai peran sebagai salah satu akses masuk dan tempat untuk transit wisatawan. Masyarakat di desa tersebut memiliki peran dalam menyiapkan beberapa kebutuhan wisatawan serta melibatkan diri dalam mengurus wisatawan hingga di TNK. Warga desa ini belum mampu memanfaatkan kunjungan wisatawan secara optimal sebagai potensi keuntungan ekonomi. Warga masyarakat yang tergabung dalam Kelompok Sadar Wisata (POKDARWIS) perlu mengidentifikasian potensi daya tarik wisata yang ada baik itu budaya, agro, maupun wisata alamnya serta menyusun program dan kegiatan pengembangan daya tarik wisata tersebut. Metode yang digunakan adalah dengan analisis SWOT. kajian internal kepariwisataan di dusun Kabo Jaya yang meliputi aspek kekuatan (strength), kelemahan (weakness); dan kajian eksternal yang meliputi peluang (opportunity) dan ancaman (threat). Daya tarik wisata yang dimiliki antara lain Daya Tarik Wisata Alam (Prevab, Telaga Batu Arang dan Tour Susur Sungai), Daya Tarik Wisata Seni dan Budaya, Kuliner serta cinderamata, Daya Tarik Wisata Minat Khusus (Agro, Perkebunan, Peternakan). Sedangkan fasilitas yang ada antara lain dermaga kabo jaya sebagai salah satu akses pendukung menuju TNK.

Kata Kunci : Ekowisata, Daya tarik Wisata, Program, Pengembangan

\section{Abstract}

The emergence of the concept of eco-tourism is one of the alternative travel forms that adopts the principles of sustainable tourism, tourist activity is more focused on concern for the conservation of nature and culture.Kabo Jaya village which is adjacent to the Kutai National Park(TNK) has a role as one entry and transit point for travelers. People in the village have a role in preparing some of the needs of tourists and travelers involved in the care of up to KNP. Warga this village has not been able to capitalize on tourists visiting optimally as a potential economic benefits. Citizens who are members of the Travel Awareness Group (Pokdarwis) the potential need of identifying an existing tourist attraction be it cultural, agro, as well as its natural attractions as well as the development of programs and activities of the development of 
the tourist attraction. The method used is the SWOT analysis. internal review of tourism in the village of Kabo Jaya covering the aspects of strength (strength), weakness (weakness); and external assessment that includes opportunities (opportunity) and threats (threat). Tourist attraction owned by, among others, Fascination Nature (Prevab, Telaga Batu Arang and Tour Susur River), Tourist Attractions Art and Culture, Culinary and souvenirs, Special Interest Travel Attractions (Agro, Plantation, Ranch).

Keywords: Ecotourism, Tourism attractiveness, Program Development

Copyright () 2019 Politeknik Negeri Samarinda. All rights reserved.

\section{Pendahuluan (dicetak tebal 11 font)}

Pariwisata memberikan kontribusi yang nyata terhadap peningkatan ekonomi daerah. Bahkan tidak sedikit daerah yang mampu mengembangkan wilayahnya menjadi destinasi wisata akan dapat meningkatkan Pendapatan Asli daerah (PAD), yang nantinya tidak hanya menggantungkan ekonominya dari dana perimbangan semata. Pengembangan sebuah daerah menjadi destinasi/tujuan wisata tidak serta merta disulap dalam sekejap tapi tentunya diperlukan upaya yang sungguhsungguh serta kerja keras dalam mewujudkannya.

Munculnya konsep ekowisata merupakan salah satu bentuk wisata alternativ yang mengadopsi prinsip-prinsip pariwisata berkelanjutan, aktifitas wisata ini lebih fokus pada kepedulian terhadap upaya konservasi alam dan budaya, yang melibatkan masyarakat lokal mulai dari tahap perencanaan dan pengambilan keputusan sampai pada tahap pengawasan dan evaluasi, diharapkan juga dapat memberikan manfaat ekonomi bagi kesejahteraan masyarakat.

Taman Nasional Kutai (TNK) yang berlokasi di Kabupaten Kutai Timur, Propinsi Kalimantan Timur merupakan taman nasional yang memiliki lahan \pm 200.000 ha, dan di TNK ini merupakan Lokasi Taman Nasional ketiga di Indonesia yang ditunjuk sebagai pusat rehabilitasi Orang Utan. Banyak wisatawan asing yang datang ke TNK agar bisa melihat binatang tersebut di lokasi aslinya. Pelayanan terhadap turis asing tersebut bersifat seadanya, yakni wisatawan hanya diantar ke TNK oleh petugas Taman Nasional dengan tidak ada pendukung wisata yang layak.
Dusun Kabojaya di desa Swarga Bara merupakan salah satu wilayah yang berbatasan langsung dengan TNK, mempunyai peran sebagai salah satu akses masuk dan tempat untuk transit wisatawan. Masyarakat di desa tersebut memiliki peran dalam menyiapkan beberapa kebutuhan wisatawan serta melibatkan diri dalam mengurus wisatawan hingga di TNK, sehingga diharapkan dapat memberikan manfaat ekonomi langsung kepada masyarakat disekitar TNK, juga telah terjadi interaksi masyarakat dengan para wisatawan asing sehingga ada transfer pengetahuan yang akan berdampak pada nilai konservasi pada TNK.

Warga Dusun Kabojaya merupakan warga transmigrasi dari berbagai Etnis diantaranya adalah Etnis Jawa, Banjar, Bugis, Tator dan Timor. Mereka hidup berdampingan dengan rukun dan memiliki beragam potensi adat istiadat seperti budaya, kuliner, ragam kehidupan sosial masyarakat, praktek-praktek pertanian tradisional masyarakat yang dapat dikembangkan sebagai bentuk atraksi wisata. Bentuk Atraksi wisata yang ada dan telah dijual kepada para wisatawan antara lain Wisata Agro, Wisata Alam dan Wisata Budaya

Desa Kabo Jaya yang berada berdampingan dengan Taman Nasional Kutai, sangat diuntungkan dengan masuknya wisatawan yang datang berkunjung yang selalu melewati desa ini. Akan tetapi warga desa ini belum mampu memanfaatkan kunjungan wisatawan secara optimal sebagai potensi keuntungan ekonomi. Atas dasar hal tersebut perlu dilakukan pengkajian terhadap pelayanan yang diberikan kepada wisatawan, baik yang datang berkunjung ke TNK ataupun pulang setelah mengunjungi TNK.

Tujuan yang ingin dicapai dari penelitian ini adalah : 
1. Mengidentifikasian potensi daya tarik wisata yang ada baik itu budaya, agro, maupun wisata alamnya.

2. Menyusun program dan kegiatan Pengembangan daya tarik wisata.

Mengangkat citra masyarakat desa Kabo Jaya agar dapat hidup lebih sejahtera dengan memanfaatkan kunjungan wisatawan yang datang ke TNK melalui desa ini serta membuat warga desa memperoleh keuntungan secara finansial.

\section{Review Tinjauan Pustaka}

Menurut Hakim (2004), ekowisata sebagai konsep pariwisata berkelanjutan dan berwawasan lingkungan memiliki karakteristik yang berbeda dibanding dengan obyek pariwisata lainnya, yaitu : wisata yang bertanggung jawab pada konservasi lingkungan; wisata yang berperan dalam usaha-usaha pemberdayaan ekonomi masyarakat lokal; dan wisata yang menghargai budaya lokal.

Konsep ekowisata lebih dikembangkan lagi dengan konsep ekowisata berbasis masyarakat atau Community Based Ecotourism (CBE).

Selanjutnya Hadi (2007) menyatakan bahwa prinsip-psinsip ekowisata adalah meminimalkan dampak, menumbuhkan kesadaraan lingkungan dan budaya, memberikan pengalaman positif baik kepada turis (visitors) maupun penerima (host) dan memberikan manfaat dan keberdayaan masyarakat lokal. Namun, pada hakekatnva, pengertian ekowisata adalah suatu bentuk wisata yang bertanggungjawab terhadap kelestarian alam (natural area), memberi manfaat secara ekonomi dan mempertahankan keutuhan budaya bagi masyarakat setempat.

Produk wisata mencakup tiga aspek yang dikenal dengan istilah triple A (Atraksi, Amenitas, Aksesibilitas) Produk wisata dapat diartikan sebagai segala sesuatu yang dapat dijual sebagai komoditas pariwisata. Atraksi wisata terdiri dari potensi flora, fauna kondisi alam dan atraksi buatan yang merupakan hasil cipta, karya dan karsa berupa seni dan budaya masyarakat.

Ekowisata memerlukan pelayanan yang dapat dilakukan oleh masyarakat lokal. Partisipasi masyarakat yang sangat besar, justru mengurangi beban pemerintah dalam pembinaan dan pelestarian pemerintah lebih besar pada fungsi koordinasi dan pembinaan.

Desa Wisata adalah suatu bentuk integrasi antara atraksi, akomodasi dan fasilitas pendukung yang disajikan dalam suatu struktur kehidupan masyarakat yang menyatu dengan tata cara dan tradisi yang berlaku (Nuryanti, Wiendu. 1993).

Terdapat dua konsep yang utama dalam komponen desa wisata :

1. Akomodasi : sebagian dari tempat tinggal para penduduk setempat dan atau unit-unit yang berkembang atas konsep tempat tinggal penduduk.

2. Atraksi : seluruh kehidupan keseharian penduduk setempat beserta setting fisik lokasi desa yang memungkinkan berintegrasinya wisatawan sebagai partisipasi aktif seperti : kursus tari, bahasa, dan lain-lain yang spesifik.

Adapun kriteria desa wisata. Pada pendekatan ini diperlukan beberapa kriteria yaitu :

1. Atraksi wisata yaitu semua yang mencakup alam, budaya dan hasil ciptaan manusia. Atraksi yang dipilih adalah yang paling menarik dan atraktif di desa.

2. Jarak tempuh adalah jarak tempuh dari kawasan wisata terutama tempat tinggal wisatawan dan juga jarak tempuh dari ibukota provinsi dan jarak dari ibukota kabupaten.

3. Besaran desa : menyangkut masalahmasalah jumlah rumah jumlah penduduk karakteristik dan luas wilayah desa. kriteria ini berkaitan dengan daya dukung kepariwisataan pada suatu desa.

4. System kepercayaan dan kemasyarakatan merupakan aspek penting mengingat adanya aturan-aturan yang khusus pada komunitas sebuah desa, perlu dipertimbangkan adalah agama yang menjadi mayoritas dan system kemasyarakatan yang ada.

5. Ketersediaan infrastruktur : meliputi fasilitas dan pelayanan transportasi, fasilitas listrik, air bersih, drainase, telepon, dan sebagainya.

Masing-masing kriteria digunakan untuk melihat karakteristik utama suatu desa untuk kemudian menentukan apakah suatu desa akan menjadi desa dengan tipe berhenti sejenak, tipe one day trip, atau tipe tinggal inap 
Pemberdayaan masyarakat adalah proses pembangunan di mana masyarakat berinisiatif untuk memulai proses kegiatan sosial untuk memperbaiki situasi dan kondisi diri sendiri. Pemberdayaan masyarakat hanya bisa terjadi apabila warganya ikut berpartisipasi. Suatu usaha hanya berhasil dinilai sebagai "pemberdayaan masyarakat" apabila kelompok komunitas atau masyarakat tersebut menjadi agen pembangunan atau dikenal juga sebagai subyek. Disini subyek merupakan motor penggerak, dan bukan penerima manfaat atau obyek saja.

\section{Metodologi Penelitian}

Metode pengumpulan data yang digunakan dalam penelitian ini adalah melalui :

a. Wawancara yakni melakukan Tanya jawab secara langsung dengan kepala Bidang Pariwisata Dinas Kebudayaan Pariwisata Kabupaten Kutai Timur, yakni yang membidangi dan bertanggung jawab terhadap Dusun Kabo Jaya, Desa Swarga Bara serta kepada pengurus Kelompok Sadar Wisata (POKDARWIS) ECOWISATA Kabo Jaya terutama Ketua dan Sekretaris.

b. Observasi dilakukan dengan cara mengamati langsung desa Wisata Kabo Jaya dengan terjun langsung melihat rutinitas kegiatan masyarakat desa serta kegiatan wisata yang dilakukan saat ada tamu atau wisatawan yang datang berkunjung.

c. Focus Group Discussion (FGD) ; yakni melakukan kegiatan diskusi ataupun rembuk di desa tersebut dengan para tokoh-tokoh pemuka desa beserta jajaran pengurus Kelompok Sadar Wisata untuk mendengarkan masukan dan pendapat perihal kegiatan kepariwisataan di desa tersebut.

d. Telaah Dokumen atau studi pustaka yakni mengumpulkan data-data yang bersumber dari literature ; buku wisata ; profil desa dan bahan lainnya yang ada relevansinya dengan penelitian ini.

Metode teknik analisis data yang digunakan adalah dengan analisis SWOT. kajian internal kepariwisataan di dusun Kabo Jaya yang meliputi aspek kekuatan (strength), kelemahan (weakness); dan kajian eksternal yang meliputi peluang (opportunity) dan ancaman (threat).

Penelitian ini merupakan jenis penelitian yang berbentuk deskriptif kualitatif. Pengumpulan data-data dilakukan melalui dua sumber yaitu data primer yakni data yang dikumpulkan secara langsung di obyek melalui kegiatan observasi, wawancara dan diskusi (Focus Group Discusion) serta data sekunder yakni data yang bersumber dari beragam referensi baik dari studi pustaka maupun dokumen informasi dari Dinas Kebudayaan Pemuda Olahraga dan Pariwisata Kabupaten Kutai Timur.

Data yang telah dikumpulkan dapat di identifikasi terlebih dahulu, apa saja potensi kekuatan dan kelemahan dari objek yang menjadi daya tarik kepariwisataan, kemudian mengidentifikasi peluang dan ancaman dalam pengembangan. Dengan tujuan untuk menentukan program atau arah kebijakan pengembangan kepariwisataan.

\section{Hasil dan Diskusi}

Inisiasi munculnya Kabojaya menjadi destinasi wisata bermula dari salah seorang warga yang melakukan wisata ke negara lain dan melihat pengelolaan wisata yang sedemikian baiknya. Kemudian mulai berpikir untuk melihat kabojaya sebagai ekowisata dengan potensi alam yang sebenarnya jauh lebih baik dari negara yang dikunjunginya. Apalagi Dusun Kabojaya, semakin sering menjadi tempat singgah (transit) wisatawan asing sebelum masuk ke Prevab Taman Nasional Kutai. Akhirnya dibentuklah kelompok masyarakat sadar wisata atau yang lebih dikenal dengan singkatan POKDARWIS dengan nama Ekowisata Kabojaya.

Dengan semakin banyak dan meningkatnya destinasi wisata maka muncullah Kelompok Sadar Wisata (POKDARWIS). Pokdarwis ini terbentuk dengan harapan dapat menjadi wadah serta tempat informasi dalam mempromosikan potensi wisata kepada wisatawan domestik maupun mancanegara. Selain itu kehadiran Pokdarwis diharapkan dapat membantu menciptakan iklim yang kondusif terhadap perkembangan dunia pariwisata di Kutai 
Timur serta meningkatkan tatanan perekonomian yang berkelanjutan.

Berdasarkan data yang didapatkan oleh penulis pada pengurus POKDARWIS Eco Kabo Jaya bahwa pengunjung itu sudah ada sejak lama, namun mereka datang hanya numpang lewat saja, karena memang dusun Kabo jaya adalah salah satu tempat akses yang dilewati oleh para wisatawan sebelum masuk ke Prevab Mentoko Taman Nasional Kutai. Namun pengurus baru mempunyai inisiatif untuk mendokumentasikan jumlah pengunjung, yakni dengan meminta para pengunjung untuk mengisi daftar buku tamu pada pos pengurus.

Menurut analisa penulis bahwa dusun Kabojaya merupakan lokasi akses masuk ke objek wisata Prevab Mentoko TNK, wisatawan yang masuk biasanya ditemani oleh seorang guide. Para pengurus POKDARWIS Ecokabojaya hendaknya menjalin kerjasama dengan pihak travel yakni langsung dengan guide yang menemani wisatawan bahwa setelah mengunjungi objek wisata utama yakni TNK, hendaknya mereka mampir sejenak untuk merasakan berbagai daya tarik yang ada seperti sensasi wisata kuliner, wisata agro, wisata budaya, sehingga diharapkan kedepannya nanti dusun ini menjadi pilihan kedua berwisata setelah para wisatawan keluar dari Prevab Mentoko TNK di Sangatta Kutai Timur.

Potensi daya tarik wisata yang ada di desa ini, bukan hanya dari sektor pariwisata, bahkan ada dari sektor pertanian, peternakan, perkebunan, sumber daya alam dan lain-lain, berikut ini pemaparan hasil identifikasi potensi kepariwisataan yang terdapat di dusun Kabo Jaya.

\section{Daya Tarik Wisata Alam}

a. Wisata Alam Prevab.

Kutai timur dapat menjadi surga bagi para wisatawan yang ingin menikmati pesona keindahan wisata alam. Dusun kabojaya sebenarnya sebuah wilayah yang menjadi salah satu pintu masuk menuju Prevab yaitu pusat penelitian orang utan di Taman Nasional Kutai. Taman Nasional Kutai sendiri menjadi tujuan para wisatawan domestik maupun manca yang ingin menikmati keindahan alam, karena di taman nasional Kutai masih banyak satwa liar yang masih hidup, seperti orang utan (pongo satyrus), owa kalimantan (Hylobates muelleri), bekantan (Nasalis
Larvatus), kera ekor panjang (Macaca fascicularis), Beruk (M.nemestrina), kukang (Nytecebus coucang borneanus), banteng (Bos javanicus lowi), rusa sambar (Cervus unicolor brookei), kijang (Muntiacus muntjak pleiharicus), kancil (Tragulus javanicus kklossi), dan lain sebagainya.

Gambar 1. Pusat Penelitian Orang Utan di TNK

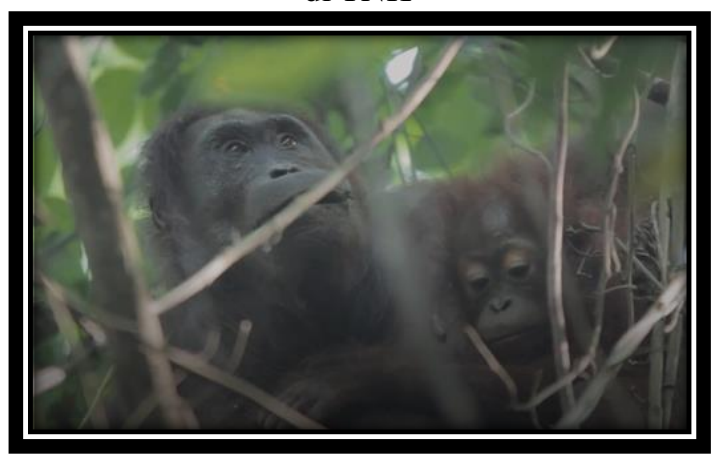

Sumber : Dokumentasi POKDARWIS Eco Kabo Jaya 2015

Prevab merupakan areal konservasi hutan yang lokasinya berada di tepi Sungai Sangatta persis di wilayah dusun kabo Jaya, di dalam kampung Jawa. Tempat ini masih masuk dalam areal Taman Nasional Kutai (TNK). Di dalam areal hutan konsevasi ini terdapat stasiun penelitian orang utan atau lebih dikenal dengan sebutan Kamp Kakap, selain itu disini juga terdapat Pusat Pendidikan Lingkungan Hidup (PPLH) dilengkapi dengan jalur interpretasi yang disebut Rute KanCiL (Pendidikan Cinta Lingkungan).

Kawasan ini merupakan sasaran tujuan kunjungan favorit bagi wisatawan asing yang ingin melihat secara langsung aktivitas keseharian orang utan hidup di alam liar serta berbagai jenis satwa lainnya seperti monyet ekor panjang, beragam jenis burung dan lain-lain. Wisatawan juga dapat menikmati keindahan pemandangan hutan hujan tropis dataran rendah

\section{b. Wisata Telaga Batu Arang}

Salah satu perusahaan batubara di Kabupaten Kutai Timur ini berhasil menyulap bekas galian batu bara menjadi objek wisata yang menarik untuk dikunjungi. Namanya Telaga Batu Arang. Nama tersebut dipilih karena memang kawasan tersebut dulunya adalah tempat galian batu arang alias batubara. KPC 
melalui program pascatambangnya kemudian berupaya mengembalikan kondisi lahan tersebut sedekat mungkin dengan keadaan awal. Di area seluas 270 hektare ini seluruhnya sudah tampak hijau karena ditumbuhi pepohonan. Luas Telaga Batu Arang sendiri sekitar 12 hektare dengan kedalaman 35 meter.

Kawasan pascatambang ini mulai direklamasi sejak 2001 Lokasi ini juga telah ditetapkan sebagai zona wisata pascatambang oleh pemerintah Kabupaten Kutai Timur pada 1 April 2013. Meskipun demikian lokasi ini belum terbuka untuk masyarakat umum.

\section{c. Tour Sungai}

Potensi Wisata Sungai yang mengalir persis disamping desa ini menawarkan paket susur sungai Sangatta yang bertujuan melihat kehidupan yang nyata disepanjang sungai dan dapat digunakan untuk proses pembelajaran buat anakanak sekolah mengenai vegetasi yang ada disepanjang alur sungai Sangatta. Di Sungai ini pula merupakan salah satu akses menuju ke Prevab Taman Nasional Kutai.

Gambar 2. Susur Sungai Tour

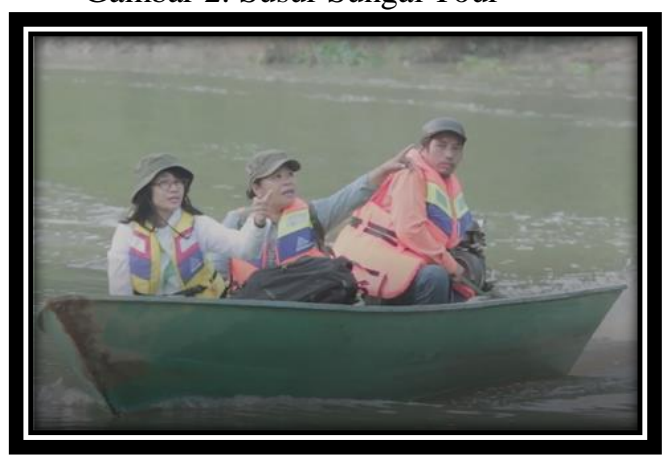

Sumber : Dokumentasi POKDARWIS Eco Kabo Jaya 2015

\section{Daya Tarik Wisata Seni \& Budaya}

a. Potensi Wisata Seni dan Budaya

Di dusun KaboJaya terdapat hal yang unik terkait dengan toleransi ragam budaya 5 etnis suku yang hidup berdampingan, yang terdiri atas 5 kampung, antara lain Banjar, Toraja, Bugis, Timor dan Jawa. Mereka hidup damai berdampingan di dusun tersebut. Wisata Tour Kampung di Dusun Kabo Jaya Desa Swarga Bara dengan mengelilingi kampung dan melihat budaya dari 5 etnis sambil menikmati suasana dusun Kabojaya dapat dijelajahi oleh wisatawan sehingga pengunjung dapat melihat dan merasakan beraneka ragam seni dan budaya antara lain upacara adat seperti perkawinan / kelahiran / kematian, dan tarian tradisional. Pengunjung juga bisa sambil belajar membuat makanan khas bugis, belajar membatik dengan corak khas Kalimantan, belajar membuat daur ulang kertas koran dan sampah plastik sebagai hasil kerajinan tangan.

Gambar 3. Tarian Penyambutan Tamu Gabungan dari 5 etnis suku

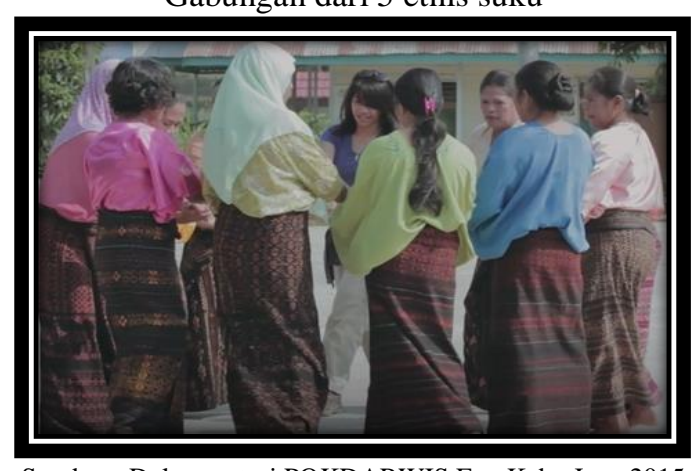

Sumber : Dokumentasi POKDARWIS Eco Kabo Jaya 2015

Eco kabojaya juga memiliki homestay yang dikelola masyarakat sekitar. Dengan slogan "Datang, Rasakan dan Peduli" wisatawan ekokabojaya tidak hanya sekedar berkunjung dan menikmati alam tapi juga ikut bertanggung jawab terhadap pelestariannya. Dengan adanya keanekaragaman ini kita dapat menikmati aneka seni dan budaya khas masing-masing suku.

b. Potensi Wisata Kuliner

Dusun Kabo Jaya Desa Swarga Bara juga mempunyai makanan tradisional dari kelima etnis. Mulai dari Kudapan sampai menu utama, sperti : barongko, dadar gulung beras ketan, ongol-ongol, pais pisang, singkong goreng, pakja-pakja, sayur asam kutai, asam laos, cemba dan masih banyak lainnya. Untuk merasakan kuliner khas Kabo Jaya tersebut, pengunjung bisa datang setiap hari Sabtu sore di Bazaar kuliner Kabojaya tepatnya di lapangan dusun Kabojaya.

Gambar 4. Potensi Wisata Kuliner 


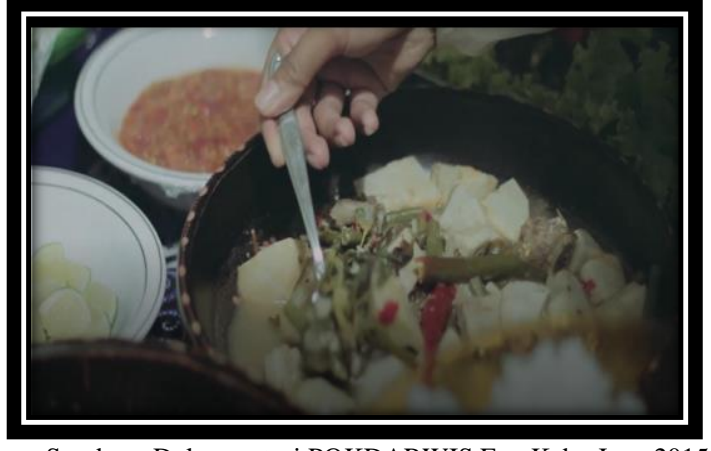

Sumber : Dokumentasi POKDARWIS Eco Kabo Jaya 2015

Desa ini juga menawarkan souvenir atau buah tangan yang dapat dibawa pengunjung sebagai oleh-oleh ; seperti kaos Ekokabojaya, gantungan kunci, kerajinan kertas koran bekas dan sampah plastik, batik khas Kutai Timur yakni wakaroros, bibit-bibit tanaman.

\section{Cinderamata.}

Gambar 5. Seni membatik Motif Wakaroros

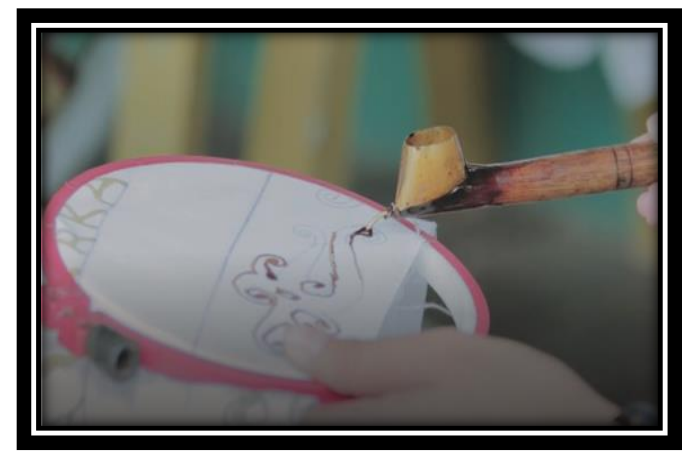

Sumber : Dokumentasi POKDARWIS Eco Kabo Jaya 2015

Desa ini juga menawarkan souvenir atau buah tangan yang dapat dibawa pengunjung sebagai oleh-oleh ; seperti kaos Ekokabojaya, gantungan kunci, kerajinan kertas koran bekas dan sampah plastik, batik khas Kutai Timur yakni wakaroros, bibit-bibit tanaman.

Gambar 6. Hasil Kerajinan Sebagai Cinderamata

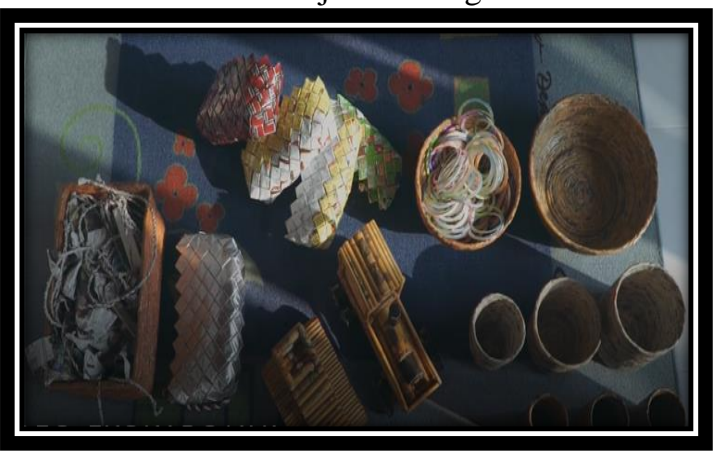

Sumber : Dokumentasi POKDARWIS Eco Kabo Jaya 2015

\section{Daya Tarik Wisata Minat Khusus}

a. Potensi Wisata Agro :
Sektor pertanian sebagai salah satu sektor primer yang memberikan kontribusi cukup besar bagi pertumbuhan ekonomi di Dusun Kabo Jaya, Desa Swarga Bara, seperti paria, terong, kacang-kacangan, bawang, jagung, cabai, jahe merah, padi gunung.

Gambar 7. Jagung,

Sebagai Salah Satu Produksi Pertanian

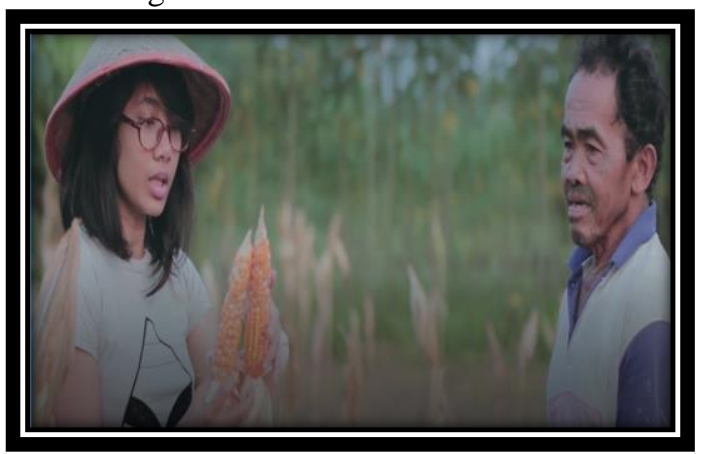

Sumber : Dokumentasi POKDARWIS Eco Kabo Jaya 2015

\section{b. Potensi Wisata Perkebunan}

Sektor perkebunan juga tersebar pada 5 kampung yang ada pada dusun Kabo jaya dan sangat membantu perekonomian masyarakat setempat seperti ; buah pisang, salak, sirsak, jeruk, papaya, nenas.

\section{c. Potensi Wisata Peternakan}

Sektor peternakan merupakan salah satu potensi yang dimiliki yakni Pengembangan Sapi Terpadu (PESAT) dibawah binaan Manajemen KPC, dengan memanfaatkan lahan pasca tambang. Pada arena lahan seluas kurang lebih 22 hektare ini, perusahaan mengembangkan peternakan sapi yang dilengkapi dengan lahan pengembalaan seluas 14 hektare.

Gambar 5.8 Peternakan Sapi Terpadu (PESAT)

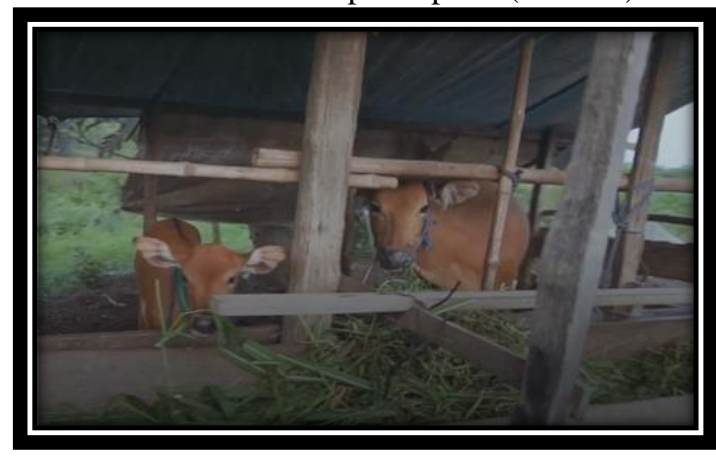

Sumber : Dokumentasi POKDARWIS Eco Kabo Jaya 2015 
Selain itu juga masih ada area kebun rumput gajah seluas 2 hektare, embung air seluas 1 hektare dan fasilitas kandang yang tersambung dengan pengolahan kotoran sapi menjadi biogas.

Tabel 1. Tabel Kajian Internal

\begin{tabular}{|c|c|c|c|}
\hline $\mathbf{N}$ & Kekuatan & $\mathbf{N}$ & Kelemahan \\
\hline 1 & $\begin{array}{l}\text { Terdapat } 5 \text { etnis yang } \\
\text { beragam seperti Jawa, } \\
\text { Bugis, Banjar, Timor } \\
\text { dan Toraja yang saling } \\
\text { hidup berdampingan, } \\
\text { rukun, aman dan damai }\end{array}$ & 1 & $\begin{array}{l}\text { Belum adanya event atau } \\
\text { kegiatan yang dapat } \\
\text { memadukan kegiatan } \\
\text { dari semua etnis yang } \\
\text { ada }\end{array}$ \\
\hline 2 & $\begin{array}{l}\text { Dermaga menjadi Akses } \\
\text { pintu masuk utama } \\
\text { sekaligus juga pintu } \\
\text { keluar bagi wisatawan } \\
\text { yang ingin ke Taman } \\
\text { Nasional Kutai }\end{array}$ & 2 & $\begin{array}{l}\text { Daya tarik wisata yang } \\
\text { utama berada di Wilayah } \\
\text { Taman Nasional Kutai. } \\
\text { Dusun Kabo Jaya belum } \\
\text { menjadi sasaran sebagai } \\
\text { destinasi wisata } \\
\text { potensial. }\end{array}$ \\
\hline 3 & $\begin{array}{lr}\begin{array}{l}\text { Pernah } \\
\text { pengakuan }\end{array} & \begin{array}{r}\text { mendapat } \\
\text { sebagai }\end{array} \\
\text { POKDARWIS } & \text { terbaik } \\
\text { ke-1 di Propinsi Kaltim } & \text { Kal } \\
\text { dan terbaik ke-6 se- } \\
\text { Indonesia }\end{array}$ & 3 & $\begin{array}{l}\text { Kesadaran dan } \\
\text { pemahaman masyarakat } \\
\text { tentang arti penting } \\
\text { kepariwisataan dan Sapta } \\
\text { Pesona belum optimal. }\end{array}$ \\
\hline 4 & 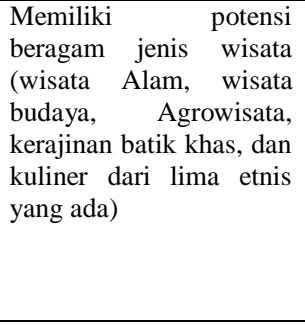 & 4 & 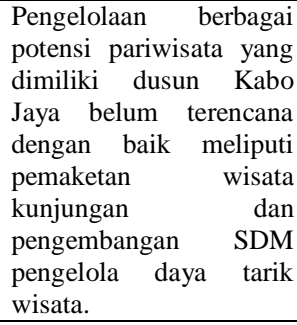 \\
\hline 5 & $\begin{array}{lr}\text { Terjalinnya } & \text { kerjasama } \\
\text { antara pihak } & \text { pengelola } \\
\text { TNK dengan } & \text { pengurus } \\
\text { POKDARWIS } & \text { yang } \\
\text { dituangkan } & \text { dalam } \\
\text { bentuk } & \text { nota } \\
\text { kesepahaman } & \text { ataupun } \\
\text { MOU } & \end{array}$ & 5 & 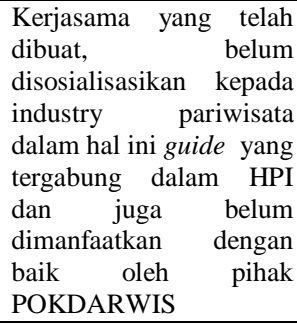 \\
\hline 6 & $\begin{array}{l}\text { Pengadaan } \\
\text { sebanyak } 2 \text { unit oleh } \\
\text { pihak TNK untuk } \\
\text { operasional } \\
\text { POKDARWIS dalam } \\
\text { hal pengantaran tamu ke } \\
\text { dalam wilayah TNK }\end{array}$ & 6 & $\begin{array}{l}\text { Belum tersedianya live } \\
\text { jaket (pelampung) untuk } \\
\text { keselamatan para } \\
\text { penumpangnya } \\
\text { menyebrang. }\end{array}$ \\
\hline 7 & $\begin{array}{l}\text { Badan Usaha Milik Desa } \\
\text { di Kabo Jaya sudah } \\
\text { berjalan dengan baik dan } \\
\text { sudah mendapatkan } \\
\text { keuntungan finansial } \\
\text { bagi POKDARWIS dari } \\
\text { peternakan bebek yang } \\
\text { disupply ke "Bebek pak } \\
\text { Endut" }\end{array}$ & 7 & $\begin{array}{l}\text { Bahan bakunya atau } \\
\text { bibit dari bebek tersebut } \\
\text { masih mengambilnya } \\
\text { dari luar daerah, belum } \\
\text { bisa produksi sendiri, } \\
\text { sehingga potensi } \\
\text { keuntungan masih belum } \\
\text { optimal. }\end{array}$ \\
\hline 8 & $\begin{array}{l}\text { Motif Batik Wakaroros } \\
\text { dengan ciri khas } \\
\text { pewarnaan dengan } \\
\text { bahan dasar dari alam } \\
\text { sebagai Souvenir dari } \\
\text { dusun Kabo }\end{array}$ & 8 & $\begin{array}{l}\text { Belum memiliki hak } \\
\text { paten dan juga belum } \\
\text { ditetapkan melalui } \\
\text { peraturan daerah sebagai } \\
\text { ciri khas baju batik bagi } \\
\text { masyarakat Kutim. }\end{array}$ \\
\hline
\end{tabular}

Sumber : Diolah Penulis 2019

Pengembangan terbaru, Pesat KPC tak hanya digunakan untuk mengembang biakan sapi potong, namun belakangan juga digunakan untuk ternak sapi perah. "Susunya kemudian dijadikan bahan untuk olahan lain seperti yogurt, bahan es krim dan susu segar. Hasilnya dipasarkan oleh pelaku UKM (usaha kecil menengah) binaan PT KPC. Pesat, saat ini sudah menjelma menjadi pusat pengembangan sapi, sekaligus sumber daya manusia bidang peternakan sapi di Kutim.

Selain sapi, saat in juga terdapat peternakan bebek yang sudah mulai berkembang. Dusun Kabo Jaya menjadi pemasok pemenuhan daging bebek untuk restoran yang sudah punya nama seperti "bebek Pak Ndut" yang sudah bekerjasama melalui bumdes yang dikelola oleh anggota POKDARWIS Eco Kabo Jaya.

\section{B. Analisis SWOT}

Di bagian ini, kami menguraikan kajian internal kepariwisataan di dusun Kabo Jaya yang meliputi aspek kekuatan (strength), kelemahan (weakness); dan kajian eksternal yang meliputi peluang (opportunity) dan ancaman (threat). Melalui tabel SWOT akan diketahui isuisu kepariwisataan yang dihadapi dusun Kabo Jaya.

Semua permasalahan yang terkait dengan lingkungan internal dan eksternal akan di analisa untuk menentukan program atau arah kebijakan pengembangan kepariwisataan saat ini dan ke depan.

\section{Kajian Internal Kepariwisataan Dusun kabo Jaya \\ Matriks kajian internal} kepariwisataan Dusun Kabo Jaya, Desa Swarga Bara adalah sebagai berikut:

\section{Kajian Eksternal Kepariwisataan Dusun kabo Jaya}

Matriks kajian eksternal kepariwisataan Dusun Kabo Jaya, Desa Swarga Bara adalah sebagai berikut: 
Tabel 2. Tabel Kajian Eksternal

\begin{tabular}{|c|c|c|c|}
\hline $\mathbf{N}$ & Peluang & $\begin{array}{l}\mathbf{N} \\
\mathbf{0}\end{array}$ & An \\
\hline 1 & $\begin{array}{l}\text { Beragamnya daya tarik } \\
\text { wisata yang dimiliki } \\
\text { oleh dusun Kabo Jaya } \\
\text { dapat menjadi salah } \\
\text { satu icon pariwisata di } \\
\text { Kutai Timur, berbasis } \\
\text { wisata alam, budaya, } \\
\text { agrowisata. }\end{array}$ & 1 & $\begin{array}{l}\text { Persaingan kualitas } \\
\text { destinasi yang semakin } \\
\text { variatif. }\end{array}$ \\
\hline 2 & $\begin{array}{l}\text { Usulan pembangunan } \\
\text { Dermaga yang sudah } \\
\text { masuk kedalam bagian } \\
\text { perencanaaan. Dengan } \\
\text { akan dibangunnya } \\
\text { dermaga kapal } \\
\text { ketinting, maka akan } \\
\text { berpeluang untuk } \\
\text { berperan lebih baik } \\
\text { bagi POKDARWIS } \\
\text { dalam hal pelayanan } \\
\text { pengantaran tamu }\end{array}$ & 2 & $\begin{array}{l}\text { Kesiapan daerah dalam } \\
\text { mengembangkan sektor } \\
\text { pariwisata masih belum } \\
\text { kuat terutama dalam hal } \\
\text { SDM pariwisata serta } \\
\text { kualitas sarana dan } \\
\text { prasarana untuk } \\
\text { menunjang aksesibilitas } \\
\text { serta kenyamanan } \\
\text { wisatawan. }\end{array}$ \\
\hline 3 & \begin{tabular}{lr} 
Dusun Kabo Jaya \\
dapat menjadi & pusat \\
wisata agro bagi dunia \\
pendidikan \\
Kabupaten di \\
\multicolumn{2}{l}{ Timur, sebagai bagian } \\
dari wisata edukasi
\end{tabular} & 3 & \begin{tabular}{lr} 
Belum & \multicolumn{2}{r}{ meratanya } \\
perkembangan & wisata \\
agro baik itu & musim \\
panen maupun & musim \\
tanam dalam & 9 sektor \\
pertanian & dan \\
perkebunan. &
\end{tabular} \\
\hline 4 & $\begin{array}{l}\text { Keanekaragaman } \\
\text { produk wisata yang } \\
\text { ada di Kabo jaya } \\
\text { belum dapat dijual } \\
\text { secara massal maupun } \\
\text { individu }\end{array}$ & 4 & $\begin{array}{l}\text { Belum terkonsepnya } \\
\text { paket wisata yang layak } \\
\text { jual beserta harga-harga } \\
\text { dan fasilitas-fasilitas } \\
\text { yang didapat }\end{array}$ \\
\hline 5 & $\begin{array}{lr}\text { Tersedia prasarana } \\
\text { umum dan fasilitas } \\
\text { pariwisata, } \\
\text { diantaranya Akses } \\
\text { jalan yang baik, dan } \\
\text { sangat dekat dengan } \\
\text { pusat rakota } \\
\text { kabupaten, serta } \\
\text { tersedianya akomodasi } \\
\text { berupa homestay, } \\
\text { warung makan, yang } \\
\text { dapat dimanfaatkan } \\
\text { sebagai pendukung } \\
\text { dan penunjang } \\
\text { kenyamanan } \\
\text { wisatawan. }\end{array}$ & 5 & $\begin{array}{lr}\text { Belum } & \text { maksimalnya } \\
\text { penguatan } & \text { kerjasama } \\
\text { kemitraan } & \text { antar usaha } \\
\text { pariwisata } & \text { seperti Biro } \\
\text { Perjalanan } & \text { dan } \\
\text { Himpunan } & \text { Pramuwisata } \\
\text { Indonesia r dengan } \\
\text { pengurus POKDARWIS } \\
\text { di Dusun KaboJaya }\end{array}$ \\
\hline 6 & $\begin{array}{l}\text { Tersedia akses } \\
\text { transportasi umum } \\
\text { yang menjangkau } \\
\text { kota Sangatta melalui } \\
\text { angkutan darat. }\end{array}$ & 6 & $\begin{array}{l}\text { Ketersediaan moda } \\
\text { transportasi umum dari } \\
\text { dan menuju dusun kabo } \\
\text { jaya belum optimal. }\end{array}$ \\
\hline 7 & $\begin{array}{lr}\text { Kota } & \text { Sangatta } \\
\text { merupakan Ibukota } & \text { kabupaten dan sebagai } \\
\text { kabua } & \text { pusat pelayanan jasa di } \\
\text { Kutai Timur serta } \\
\text { posisi dusun Kabo } \\
\text { Jaya yang sangat } \\
\text { strategis, sangat dekat } \\
\text { dengan pusat kota dan } \\
\text { dekat dengan } \\
\text { perusahaan tambang } \\
\text { ternama. }\end{array}$ & 7 & $\begin{array}{l}\text { Kabupaten/kota sekitar } \\
\text { lebih gencar } \\
\text { mempromosikan } \\
\text { pariwisata dengan } \\
\text { segmentasi wisatawan } \\
\text { domestic (Kota } \\
\text { Bontang, Kota } \\
\text { Balikpapan, Kota } \\
\text { Samarinda) khusus koa } \\
\text { Balikpapan dan } \\
\text { Samarina sudah } \\
\text { didukung oleh akses } \\
\text { Bandar Udara. }\end{array}$ \\
\hline
\end{tabular}

Sumber : Diolah Penulis 2019
C. Strategi Pengembangan Berdasarkan Hasil Analisis SWOT

1. Strategi Internal (Kekuatan VS Kelemahan)

a. Menjadikan dusun Kabo Jaya sebagai icon desa wisata yang harmonis dan rukun, aman dan damai sebagai daya tarik wisata di Kabupaten Kutai Timur.

b. Membuat Event Wisata terjadwal setiap tahun dan masuk dalam calendar event Dinas Pariwisata Kutai Timur dengan memadukan kegiatan dari 5 etnis yang ada.

c. Membangun dermaga yang berkualitas sebagai titik akses point untuk masuk ke TNK.

d. Meningkatkan program pemberdayaan masyarakat dan meningkatkan sumber daya manusia bagi POKDARWIS Kabo Jaya melalui kegiatan pendidikan dan pelatihan bidang pariwisata.

e. Peningkatan SDM bagi POKDARWIS Kabo Jaya dalam memberikan pelayanan pengantaran wisatawan dari penyambutan wisatwan di dermaga hingga penjemputan di TNK.

f. Penguatan dan peningkatan kerjasama kemitraan antar usaha pariwisata seperti Biro Perjalanan dan Himpunan Pramuwisata Indonesia dengan pengurus POKDARWIS.

g. Peningkatan kerjasama yang strategis diantara pengelola Taman Nasional Kutai dengan POKDARWIS setempat serta dengan pelaku dan pengusaha dari industry pariwisata yang tergabung dalam ASITA, PHRI, BPPD Kaltim

h. Peningkatan pelayanan, saat diatas perahu ketinting dengan mengikuti standard keselamatan di atas air, serta penggunaan live jaket demi keselamatan wisatawan

i. Melalui BUMDES, memproduksi dan mengembangbiakkan pembibitan bebek secara mandiri melalui pelatihan peternakan agar dapat meningkatkan kapasitas produksi dan supply bebek.

j. Batik Wakaroros yang belum memiliki hak paten dan sebagai ciri 
khas baju batik bagi masyarakat Kutim perlu segera di bawa kebagian kemenkumham untuk mendapatkan hak paten serta perlu menetapkan melalui peraturan daerah sebagai ciri khas baju batik bagi masyarakat Kutim.

\section{Strategi Eksternal (Peluang VS Ancaman)}

a. Menjadikan Dusun kabo jaya sebagai Icon Desa Wisata berbasis Agrowisata dan Wisata Budaya

b. Menyediakan prasarana umum, fasilitas umum, dan memperbaiki fasilitas pariwisata di kawasankawasan pariwisata, terutama di sekitar Kabo Jaya untuk menunjang aksesibilitas serta kenyamanan wisatawan.

c. Penyediaan moda transportasi umum dari dan menuju dusun kabo jaya

d. Membuat dan merencanakan kepastian jadwal musim tanam dan musim panen bagi

e. sektor pertanian dan perkebunan agar dapat dipromosikan sebagai pusat wisata edukasi di bidang agro wisata dengan sasaran anak-anak sekolah di Kab. Kutim. Membuat paket wisata dan mencetaknya kedalam sebuah brosur disertai dengan daftar hargaharganya serta fasilitas yang akan di dapat.

f. Membuat target dengan meningkatkan segmentasi pasar wisatawan lokal di daerah Sangatta dan sekitarnya sebagai sasaran promosi. Kemudian meningkat lagi ke Kabupaten dan Kota lain di sekitarnya dalam wilayah KALTIM.

\section{Kesimpulan}

Berdasarkan keseluruhan uraian yang telah dikemukakan dapat disimpulkan bahwa Kabupaten Kutai Timur yang terdiri dari beragam karakteristik wilayah, diantaranya memiliki desa wisata dengan keunikan tersendiri yang mana dusun ini memiliki banyak sekali potensi wisata budaya dengan keragaman tradisi budaya yang mempesona dari ragam 5 etnis yang ada.

Pemerintah Kabupaten Kutai Timur bersama masyarakat memang harus terus berusaha untuk mengembangkan sektor kepariwisataan, agar pertumbuhan bidang ekonomi bisa dipertahankan dan kesejahteraan masyarakat dapat ditingkatkan. Kawasan dusun Kabo Jaya sebagai salah satu desa wisata berbasis budaya perlu dibina dan dikembangkan lebih lanjut, sehingga semakin memenuhi syarat dan menarik minat wisatawan untuk berkunjung kesana.

\section{References}

[1] Vander, A., J. Sherman., D. Luciano. 2001. Human Physiology: The Mecanisms of Body Function. McGraw-Hill Higher Education. New York.

[2] Shi, Z., M. Rifa'i, Y. Lee, K. Isobe, H. Suzuki. 2007. Importance of CD80/CD86CD28 interaction in the recognation of target cells by CD8+CD122+ regulatory $\mathrm{T}$ cells. Journal Immunology. $124 . \quad$ 1:121-128. (Article in Journal)

[3] Syafi'i, M., Hakim, L., dan Yanuwiyadi, B. 2010. Potential Analysis of Indigenous Knowledge (IK) in Ngadas Village as Tourism Attraction. pp. 217-234. In: Widodo, Y. Noviantari (eds.) Proceed-ing Basic Science National Seminar 7 Vol.4. Universitas Brawijaya, Malang. (Article within conference proceeding)

[4] Dean, R.G. 1990. Freak waves: A possible explanation. p. 1-65. In Torum, A., O.T. Gudmestad (eds). Water wave kinetics. CRC Press. New York. (Chapter in a Book)

[5] Astuti, A.M. 2008. The Effect of Water Fraction of Stellaria sp. on the Content of TNF- $\alpha$ in Mice (Mus musculus BALB-C). Thesis. Department of Biology. University of Brawijaya. Malang. (Thesis)

[6] Sukmana, E. Interview. 2019. 